\title{
Antibodies to a cell surface histone-like protein protect against Histoplasma capsulatum
}

\author{
Joshua D. Nosanchuk, ${ }^{1}$ Judith N. Steenbergen, ${ }^{2}$ Li Shi, ${ }^{1}$ George S. Deepe, Jr., ${ }^{3}$ \\ and Arturo Casadevall1,2 \\ ${ }^{1}$ Department of Medicine, Division of Infectious Diseases, and \\ ${ }^{2}$ Department of Microbiology and Immunology, Albert Einstein College of Medicine, New York, New York, USA \\ ${ }^{3}$ Department of Medicine, Division of Infectious Diseases, University of Cincinnati College of Medicine and \\ Veterans Affairs Hospital, Cincinnati, Ohio, USA
}

\begin{abstract}
A protective role for antibodies has not previously been described for host defense against the pathogenic fungus Histoplasma capsulatum $(\mathrm{Hc})$. Mouse mAb's were generated from mice immunized with $\mathrm{Hc}$ yeast that binds the cell surface of $\mathrm{Hc}$. Administration of mAb's before $\mathrm{Hc}$ infection reduced fungal burden, decreased pulmonary inflammation, and prolonged survival in a murine infection model. Protection mediated by mAb's was associated with enhanced levels of IL-4, IL-6, and IFN- $\gamma$ in the lungs of infected mice. The mAb's increased phagocytosis of yeast by J774.16 cells through a CR3-dependent process. Ingestion of $\mathrm{mAb}$-opsonized $\mathrm{Hc}$ by J774.16 macrophage-like cells was associated with yeast cell growth inhibition and killing. The mAb's bound to a 17-kDa antigen expressed on the surface of $H c$. The antigen was identified as a histone H2B-like protein. This study establishes that mAb's to a cell surface protein of $\mathrm{Hc}$ alter the intracellular fate of the fungus and mediate protection in a murine model of lethal histoplasmosis, and it suggests a new candidate antigen for vaccine development.
\end{abstract}

J. Clin. Invest. 112:1164-1175 (2003). doi:10.1172/JCI200319361.

\section{Introduction}

The dimorphic fungus Histoplasma capsulatum var. capsulatum $(\mathrm{Hc})$ is the most prevalent cause of fungal respiratory disease, infecting approximately 500,000 individuals in the US each year (1-3). Infection usually results in a mild, often asymptomatic respiratory illness but may progress to life-threatening systemic disease, particularly in individuals with AIDS $(4,5)$. In contrast to immunocompetent individuals, in whom dissemination is uncommon, $95 \%$ of individuals with AIDS present with disseminated disease $(5,6)$. Patients with AIDS are more likely to develop symptomatic disease that requires hospitalization and have a high fatality rate (7). Despite administration of amphotericin B, the fatality rate in severe disease (e.g., shock, respiratory failure) remains extremely high $(6,8)$. Even with highly active antiretroviral therapy (HAART) and the availability of prophylactic triazoles, there have not been significant changes in the rates of morbidity and mortality in patients with HIV infected with $\mathrm{Hc}$ (7). Since currently available medications for systemic fun-

Received for publication July 1, 2003, and accepted in revised form August 19, 2003.

Address correspondence to: J.D. Nosanchuk, Albert Einstein College of Medicine, 1300 Morris Park Avenue, New York, New York 10461, USA. Phone: (718) 430-3766; Fax: (718) 430-8701; E-mail: nosanchu@aecom.yu.edu.

Conflict of interest: The authors have declared that no conflict of interest exists.

Nonstandard abbreviations used: Histoplasma capsulatum var. capsulatum (Hc); $0.1 \%$ Tween-20 in TBS (TBST); goat anti-mouse (GAM); brain-heart infusion (BHI); monocyte chemoattractant protein-1 (MCP-1); 3-[3-cholamidopropyl)dimethylammonio]-1propanesulfonate (CHAPS). gal infections often fail to work in the setting of impaired immunity, and many AIDS patients require lifelong prophylaxis to prevent recurrent disease, new therapies are urgently needed.

$\mathrm{Ab}$ administration is associated with improved outcome in experimental infection with certain intracellular pathogens (9), but there is no evidence that humoral immunity is effective against $H c$. Protective Ab's function through diverse mechanisms, including complement-mediated lysis, enhancement or inhibition of phagocytosis, and $\mathrm{Fc}$-mediated cytokine release. Exposure to $\mathrm{Hc}$ is known to induce an $\mathrm{Ab}$ response, and the IgG fraction contains complement-fixing and precipitating Ab's (10). Passive immunization with immune serum has not been shown to mediate protection (11), B cell-deficient mice are not particularly susceptible to infection (12), and high titers of serumspecific $\mathrm{Ab}$ to $\mathrm{Hc}$ do not correlate with immunity (10). Consequently, the consensus in the field is that humoral immunity has little or no role in host defense. In fact, high titers of complement-fixing $\mathrm{Ab}$ are associated with progressive disease. Nevertheless, we hypothesized that mAb's could be identified that are active against histoplasmosis. Here we describe the generation of protective mAb's to $H c$ that bind to a histone $\mathrm{H} 2 \mathrm{~B}$-like protein on the surface of the fungus. The results suggest that the histone $\mathrm{H} 2 \mathrm{~B}$-like protein is a potential candidate for vaccine development.

\section{Methods}

Fungal strains. Hc ATCC G217B was obtained from the American Type Culture Collection (ATCC, Rockville, Maryland, USA). Hc CIB 1980 was a gift from A. 
Restrepo (Corporación para Investigaciónes Biologícas, Medellin, Colombia). Yeast cells were grown at $37^{\circ} \mathrm{C}$ in Ham's F-12 medium as described previously (13). The cells were washed three times in PBS and counted by hemacytometer. Additionally, Cryptococcus neoformans strain 24067 (ATCC), Candida albicans strain SC5314 (a gift from M. Ghannoum, Case Western Reserve University, Cleveland, Ohio, USA), Sporothrix schenckii strain CIB (a gift from A. Restrepo, Corporación para Investigaciónes Biologícas), and Saccharomyces cerevisiae strain LM23-3az (a gift from L. Marsh, Albert Einstein College of Medicine, New York, USA) were grown in Sabouraud dextrose broth (Becton Dickinson and Company, Sparks, Maryland, USA) with shaking at $37^{\circ} \mathrm{C}$. Heatinactivated Paracoccidioides brasiliensis strain 60995 yeast was a gift from A. Restrepo. For immunization studies, $H c$ were killed by heat at $56^{\circ} \mathrm{C}$ for 1 hour.

Generation and identification of $m A b^{\prime}$ 's to $\mathrm{Hc}$. Five 6- to 8week-old female BALB/c mice (National Cancer Institute, Rockville, Maryland, USA) were immunized with intraperitoneal injections of $10^{6}$ heat-inactivated $\mathrm{Hc}$ cells, which were suspended in a $1: 1(\mathrm{vol} / \mathrm{vol})$ emulsion of CFA (Sigma-Aldrich, St. Louis, Missouri, USA) and PBS. Additional doses of $10^{6}$ heat-inactivated $H c$ were administered at weeks 2, 4, and 6 after initial immunization in 1:1 (vol/vol) emulsions of incomplete Freund's adjuvant (Sigma-Aldrich) and PBS. Before, and 2 weeks after, each immunization, sera were obtained and analyzed for Ab's to $\mathrm{Hc}$. The Ab response was assessed using an $H c$ yeast cell ELISA developed for this study. $\mathrm{Hc}$ yeast cells were found to adhere to 96-well polystyrene plates (Costar 9018; Corning Inc., New York, New York, USA). The optimum number of yeast cells necessary to coat each well was $5 \times 10^{5}$ yeast per well by microscopic evaluation of the plates after serial washing in an ELISA washer (SkanWasher 400; Skatron Instruments, Lier, Norway). Wells were blocked to prevent nonspecific binding using 2\% BSA (ICN Biomedicals Inc., Aurora, Ohio, USA) and $0.05 \%$ Tween-20 in TBS for 1 hour at $37^{\circ} \mathrm{C}$. The plates were washed three times with $0.1 \%$ Tween-20 in TBS (TBST) after each incubation. Sera were serially diluted 1:2 in the blocking solution, added to wells of the $\mathrm{Hc}$-coated plates, and incubated for 1 hour at $37^{\circ} \mathrm{C}$. After washing, a 1:1,000 dilution of alkaline phosphatase-conjugated goat anti-mouse (GAM) IgG and IgM (Southern Biotechnology Associates Inc., Birmingham, Alabama, USA) was added to the wells and incubated for 1 hour at $37^{\circ} \mathrm{C}$. Ab binding was detected by addition of $p$-nitrophenyl phosphate (Sigma-Aldrich) in $1.0 \mathrm{mM} \mathrm{MgCl}_{2}$ and $50.0 \mathrm{mM}$ $\mathrm{Na}_{2} \mathrm{CO}_{3}$, pH 9.8, and measurement of OD at $405 \mathrm{~nm}$ with a Ceres 900HDi EIA Workstation (Bio-Tek Instruments Inc., Winooski, Vermont, USA).

The mouse with the highest Ab titer to $H c$ yeast cells $(1: 12,800)$ was boosted again at week 8 and used to generate hybridomas as described previously (14). The hybridomas producing Ab's that bound to $\mathrm{Hc}$, but not to the blocking solutions, were cloned twice using soft agar cloning to recover homogenous hybridoma cell lines. The heavy- and light-chain isotype of each $\mathrm{mAb}$ was determined using alkaline phosphatase-conjugated Ab's specific for the heavy-chain constant region and for $\kappa$ and $\lambda$ light chains.

Localization of binding to Hc yeast. Hc strains G217B and CIB 1980 were washed in PBS, dried on poly-Llysine-coated slides (Sigma-Aldrich), and blocked with SuperBlock (Pierce Chemical Co., Rockford, Illinois, USA). The slides were incubated with $10 \mu \mathrm{g} / \mathrm{ml}$ of $\mathrm{mAb}$ to $\mathrm{Hc}$ (mAb 3B9, 5B8, or 9C7) or an isotype-matched control ( $\mathrm{mAb} 5 \mathrm{C} 11)$ for 1 hour at $37^{\circ} \mathrm{C}$. $\mathrm{mAb} 5 \mathrm{C} 11$ is specific for lipoarabinomannan of Mycobacterium tuberculosis (15). After a wash, the slides were incubated with FITC-conjugated GAM IgM (Southern Biotechnology Associates Inc.) for 1 hour at $37^{\circ} \mathrm{C}$. The slides were washed, mounted using a 50\% glycerol/50\% PBS/0.1 M $N$-propyl gallate solution, and viewed with an Olympus AX70 microscope (Olympus Optical Co., Melville, New York, USA) equipped with a FITC filter. The reactivity of the $\mathrm{Hc}$-binding mAb's and P. brasiliensis, $S$. schenckii, S. cerevisiae, C. albicans, and C. neoformans yeast cells were also examined.

Infected tissues were examined to determine whether the mAb's could bind $H c$ in situ. C57BL/ 6 mice (6-8 weeks old; National Cancer Center, Frederick, Maryland, USA) were anesthetized with ketamine and xylazine and then intranasally infected with $5 \times 10^{6} \mathrm{Hc}$ yeast. Mice were euthanized 14 days after infection. Lung tissue was used for immunofluorescent microscopy as described above.

Immunogold transmission electron microscopy was used to determine where the mAb's bound Hc. Sections of $H c$ strain G217B were prepared for microscopy as described previously (16). Primary $\mathrm{mAb}$ was either $\mathrm{mAb}$ to $\mathrm{Hc}(9 \mathrm{C} 7,5 \mathrm{~B} 8$, or 3B9) or polyclonal murine IgM (ICN Biomedicals Inc.) as a negative control. Secondary $\mathrm{mAb}$ was GAM IgM conjugated to $5 \mathrm{~nm}$ gold (Goldmark Biologicals, Phillipsburg, New Jersey, USA). The grids were viewed with a JEOL (Tokyo, Japan) 100 CX transmission electron microscope.

$m A b$ specificity studies. To assess $m A b$ specificity, each IgM was purified, biotinylated, and used in competition experiments with the Hc yeast cell ELISA. The mAb's were purified using agarose beads conjugated to GAM IgM (Sigma-Aldrich) according to the instructions of the manufacturer. Biotinylation was accomplished by the incubation of the mAb's with an EZ-Link SulfoNHS-Biotin kit (Pierce Chemical Co.) according to the instructions of the manufacturer. A constant concentration of one of the biotinylated mAb's was incubated with varying amounts of a different nonbiotinylated $\mathrm{mAb}$ for 1 hour at $37^{\circ} \mathrm{C}$. After washing, avidin conjugated with alkaline phosphatase (Sigma-Aldrich) was added for 1 hour at $37^{\circ} \mathrm{C}$. Binding of the biotinylated $\mathrm{mAb}$ was detected as described above.

Assays of direct $m A$ effects on $\mathrm{Hc}$. The growth rate of $\mathrm{Hc}$ opsonized with either $10 \mu \mathrm{g} / \mathrm{ml}$ or $100 \mu \mathrm{g} / \mathrm{ml}$ of specific $\mathrm{mAb}$ was compared with that of yeast grown in the presence of an isotype-matched control mAb. The $\mathrm{Hc}$ 
yeast cells were grown in F-12 medium as described above, aliquots were removed at various intervals, and the number of cells was determined by counting with a hemacytometer. To assess for agglutination, yeast cells were incubated with or without $\mathrm{Hc}$-binding $\mathrm{mAb}$ (concentrations ranging from 1 to $1,000 \mu \mathrm{g} / \mathrm{ml}$ ) for 2 hours at $37^{\circ} \mathrm{C}$ and viewed by a microscope. The cells were also plated onto brain-heart infusion (BHI) agar (Becton Dickinson) for CFU determination.

To determine whether opsonization of $\mathrm{Hc}$ with the $\mathrm{mAb}$ 's resulted in the permeabilization of the fungus, protein release was assessed in the presence and absence of specific mAb (17). Protein release was assayed for $5 \times 10^{6}$ organisms incubated in PBS with 10 $\mu \mathrm{g} / \mathrm{ml}$ or $100 \mu \mathrm{g} / \mathrm{ml}$ of $H c$-binding $\mathrm{mAb}(3 \mathrm{~B} 9,5 \mathrm{~B} 8$, or 9C7) or control mAb (5C11), or PBS for 15 minutes at $37^{\circ} \mathrm{C}$, and then collected by centrifugation. Yeast cells were also incubated in PBS alone. The supernatant was incubated with $10 \mu \mathrm{M}$ of the thiol-specific fluorophore ThioGlo 1 (Calbiochem, EMD Biosciences Inc., San Diego, California, USA) in the presence and absence of the protein-denaturing agent SDS. Thiol-containing proteins were detected using a fluorescent plate reader with excitation and emission wavelengths of $405 \mathrm{~nm}$ and $535 \mathrm{~nm}$, respectively. The proteins were quantified by subtraction of the fluorescence due to released glutathione (i.e., from the signal obtained in the absence of SDS) from total fluorescence. The permeabilizing antimicrobial peptide mellitin (Sigma-Aldrich) was used as a positive control.

CFU and survival studies. Two hours before infection, 6- to 8-week-old BALB/c or C57BL/6 mice (National Cancer Institute) were injected intraperitoneally with $100 \mu \mathrm{g}$ of $\mathrm{mAb}$ to $\mathrm{Hc}$ (9C7, 5B8, or 3B9), isotypematched control ( $\mathrm{mAb} 5 \mathrm{c} 11)$, or PBS. Prior to use in the animal and macrophage studies, the mAb's and PBS were screened with the Limulus amebocyte assay (BioWhittaker Inc., Walkersville, Maryland, USA) to assure that the reagents were endotoxin free. To produce a sublethal infection, mice were anesthetized and infected intranasally with $5 \times 10^{6} \mathrm{Hc}$ yeast. Mice were euthanized 14 days after infection. The left upper lobe of the lung was removed and placed into formalin for histology. For CFU determination, the remaining lung tissue, spleen, and liver were homogenized separately, diluted, plated on BHI agar with glucose $(10 \mathrm{~g} / \mathrm{l})$, cysteine $(0.1 \mathrm{~g} / \mathrm{l})$, penicillin-streptomycin, and sheep red blood cells $(50 \mathrm{ml} / \mathrm{l}$; Colorado Serum Co., Denver, Colorado, USA), and incubated at $37^{\circ} \mathrm{C}$.

Lethal infections were also induced by intranasal infection of C57BL/ 6 mice with $1.25 \times 10^{7} \mathrm{Hc}$ yeast. Mice were given $100 \mu \mathrm{g} \mathrm{mAb}$ to $\mathrm{Hc}$ (9C7, 5B8, or 3B9), control $\mathrm{mAb}$ (5C11), or PBS prior to infection and observed twice daily for survival. Survival experiments were also performed in which mice that received $\mathrm{mAb}$ $9 \mathrm{C} 7$, control $\mathrm{mAb}$, or PBS prior to infection were subsequently given subinhibitory doses of amphotericin $B$. Administration of subinhibitory concentrations of amphotericin B in combination with GM-CSF has been shown to protect lethally infected mice (18). Amphotericin B sodium desoxycholate (Sigma-Aldrich) was administered intraperitoneally three times weekly beginning the day after infection at a dose of 0.125 $\mu \mathrm{g} / \mathrm{kg}$. A third survival study examined the effect of preincubation of $\mathrm{mAb}$ and $\mathrm{Hc}$ prior to infection. Since IgM mAb may not efficiently penetrate lung tissue, mice were infected intranasally with lethal concentrations of $\mathrm{Hc}$ yeast that were preincubated for 1 hour at $37^{\circ} \mathrm{C}$ with $1 \mathrm{mg}$ of $\mathrm{mAb} 9 \mathrm{C} 7$, control $\mathrm{mAb}$, or PBS.

Cytokine and chemokine determinations. C57BL/ 6 mice were infected as described above with $5 \times 10^{6} \mathrm{Hc}$ strain G217B. Experimental groups were given purified $\mathrm{mAb}$ 9C7 or PBS 2 hours before infection with yeast. Shaminfected groups were given $\mathrm{mAb} 9 \mathrm{C} 7$ or PBS 2 hours before intranasal administration of PBS. Mice were sacrificed at days 2 and 7 postinfection, and the lungs were homogenized in $2 \mathrm{ml}$ PBS in the presence of protease inhibitors (Complete Mini; Boehringer Ingelheim Pharmaceuticals Inc., Ridgefield, Connecticut, USA). The homogenates were centrifuged at $6,000 \mathrm{~g}$ for 10 minutes to remove cell debris, and the supernatant was frozen at $-80^{\circ} \mathrm{C}$ until tested. The supernatants were assayed for IL-2, IL-4, IL-6, IL-10, IL-12p70, monocyte chemoattractant protein-1 (MCP-1), TNF- $\alpha$, and IFN- $\gamma$ using ELISA (Becton Dickinson Biosciences Pharmingen, San Diego, California, USA; and R\&D Systems Inc., Minneapolis, Minnesota, USA). The detection limits of cytokine assays are $3.1 \mathrm{pg} / \mathrm{ml}$ for IL-2, $7.8 \mathrm{pg} / \mathrm{ml}$ for IL-4, $15.6 \mathrm{pg} / \mathrm{ml}$ for IL- 6 and TNF- $\alpha, 31.3 \mathrm{pg} / \mathrm{ml}$ for IL-10 and IFN- $\gamma$, and $62.5 \mathrm{pg} / \mathrm{ml}$ for IL-12p 40 , as stated by the manufacturer. The detection limit of the chemokine assay is $15.6 \mathrm{pg} / \mathrm{ml}$ for MCP- 1 , as determined by the manufacturer.

Phagocytosis assays. The macrophage-like cell J774.16 is derived from a reticulum cell sarcoma and has been extensively used to study phagocytosis of intracellular microbes (19). J774.16 cells were cultured in DMEM with $10 \%$ heat-inactivated FCS, $10 \%$ NCTC-109 medium, and $1 \%$ nonessential amino acids. $\mathrm{CHO}$ cell lines stably transfected with LFA1 (CD18/CD11a), CR1 (CD35), CR3 (CD18/CD11b), and CR4 (CD18/CD11c) were obtained from D.T. Golenbock (University of Massachusetts Medical School, Boston, Massachusetts, USA). CHO cell lines were cultured in $\alpha$ minimum essential medium (Life Technologies Inc., Carlsbad, California, USA) with $10 \%$ heat-inactivated FCS. All macrophages were plated at $10^{5}$ cells per well in an eight-chamber polystyrene tissue-culture glass slide (Becton Dickinson) and grown overnight before use in the phagocytosis assays.

Phagocytosis assays with $\mathrm{Hc}$ and macrophages using heat-killed yeast cells labeled with a fluorochrome were done according to standard protocols (20). Hc cells were collected after 3 days of growth, washed three times in PBS, and heat-killed. Yeast cells were incubated with $0.1 \mathrm{mg} / \mathrm{ml}$ Oregon Green 488 isothiocyanate (Molecular Probes Inc., Eugene, Oregon, USA) for 20 minutes at room temperature and then washed in PBS. 
The labeled cells were incubated with $\mathrm{mAb} 9 \mathrm{C} 7$, nonspecific $\mathrm{mAb} 5 \mathrm{C} 11$, or PBS for 1 hour at $37^{\circ} \mathrm{C}$. Labeling with Oregon Green did not inhibit $\mathrm{mAb}$ specific to $\mathrm{Hc}$ from binding the yeast (data not shown). After washing, the samples were added to the macrophage monolayer at an effector-to-target ratio of $2: 1$, and the suspension was incubated at $37^{\circ} \mathrm{C}$ for 2 hours in media without complement. Trypan blue $(1 \mathrm{mg} / \mathrm{ml}$ in PBS) was added for 15 minutes at room temperature to quench the fluorescence of uningested organisms. The phagocytic index was determined by microscopic examination at a magnification of $\times 600$. For each experiment, five fields in each well were counted, and at least 200 macrophages were analyzed in each well. All conditions were tested in triplicate. The phagocytic index was the ratio of intracellular yeast to the number of macrophages counted.

Ab's to mouse CD14 (clone rmC5-3, rat [LOU] IgG1), CD35 (clone 8C12, rat [SD] IgG2a), CD18 (clone M18/2, rat IgG2a), CD11a (clone M17/4, rat [WistarFurth] IgG2a), CD11b (clone M1/70, rat [DA] IgG2b), and CD11c (clone HL3, Armenian hamster IgG, group 1) were obtained from Becton Dickinson Pharmingen. The cell-receptor mAb's $(20 \mu \mathrm{g} / \mathrm{ml})$ were added to the macrophage monolayer 1 hour before the addition of the fungi that had been incubated with or without $\mathrm{mAb}$ specific for $\mathrm{Hc}$. The phagocytosis assay continued as described above.

Transfected CHO cells $\left(2 \times 10^{4}\right.$ per well $)$ were added to eight-chamber tissue-culture slides and grown overnight in $\alpha$ minimum essential medium. The cells were washed three times, and $H c$ incubated with or without yeast-specific mAb $\left(4 \times 10^{4}\right.$ per well; effectorto-target ratio 2:1) were added in $\alpha$ minimum essential medium without FCS. The remainder of the phagocytosis assay was performed as described with the macrophage monolayers described above.

Fate of Hc phagocytosed in the presence or absence of $m A b$ specific to the fungus. Intracellular replication of $\mathrm{Hc}$ preincubated with or without $\mathrm{mAb}$ specific to the yeast was quantified by RIA as described by Newman et al. (21). Macrophages were incubated overnight in 96-well tissueculture plates and eight-well tissue-culture slides. $\mathrm{Hc}$ strain $\mathrm{G} 217 \mathrm{~B}$ cells preincubated with $\mathrm{mAb} 9 \mathrm{C} 7$ or $5 \mathrm{C} 11$ were added (effector-to-target ratio 5:1) with fresh medium for 1 hour to permit phagocytosis, and then $10 \mu \mathrm{M}$ chloroquine was added as a postendocytic inhibitor. Fresh medium with or without $\left[{ }^{3} \mathrm{H}\right]$ leucine was added to the experimental wells. After 24 hours, unlabeled leucine and bleach were added. The contents of the wells were transferred to glass fiber filters by an automated harvester (Skatron Instruments, Sterling, Virginia, USA) and extensively washed to remove unincorporated tritium, and the incorporated tritium was quantified by scintillation counting (1414 liquid scintillation counter; PerkinElmer Life and Analytical Sciences Inc., Boston, Massachusetts, USA). The macrophages and yeast were simultaneously used to determine the phagocytic index as described above. The phagocytic index was used to normalize the counts according to the number of intracellular yeast at the time the $\left[{ }^{3} \mathrm{H}\right]$ leucine was added.

To determine whether the growth of intracellular $\mathrm{Hc}$ yeast was affected by prior opsonization with protective $\mathrm{mAb}$, yeast cells preincubated with $\mathrm{Hc}$-specific $\mathrm{mAb}$ 9C7, control mAb 5C11, or PBS were incubated with macrophage monolayers for 24 hours. Yeast cells were similarly incubated in wells without macrophages. The macrophages were lysed by the addition of sterile $\mathrm{dH}_{2} \mathrm{O}$, and the contents of the wells were plated onto $\mathrm{BHI}$ agar to determine CFUs. The percentage growth was determined by comparison of the CFUs from $\mathrm{Hc}$ grown with macrophages to the CFUs from yeast grown in medium alone.

Identification of the $m A$ b-binding antigen. Cell wall/cell membrane preparations of $H c$ were generated according to published protocols $(22,23)$. Western blot analysis was performed by electrophoresis of the protein preparations in 10-20\% SDS-PAGE gels (Bio-Rad Laboratories Inc., Hercules, California, USA), and the separated proteins were electroblotted onto nitrocellulose membranes. The membranes were blocked with $2 \%$ nonfat dried milk in TBS, incubated with $\mathrm{mAb} 3 \mathrm{~B} 9,5 \mathrm{~B} 8$, or 9C7, washed in TBST, and incubated with GAM IgM conjugated to HRP. The samples were developed with ECL substrate (SuperSignal; Pierce Chemical Co.) and exposed on X-Omat AR film (Eastman Kodak Co., Rochester, New York, USA). Samples were also treated with $\mathrm{N}$-glycosidase, sodium metaperiodate, or proteinase K (Sigma-Aldrich) before Western blot analysis to determine whether the immunoreactive components of the preparations were carbohydrates or proteins.

The preparations were further purified by serial treatment with $1 \mathrm{mM}$ DTT, 1\% Triton, $10 \mathrm{mM}$ 3-[(3-cholamidopropyl)dimethylammonio]-1-propanesulfonate (CHAPS), and $100 \mathrm{mM}$ sodium carbonate, $\mathrm{pH} 10$ (Sigma-Aldrich). In situ digestion to isolate the desired protein was performed as described previously (24), and mass spectroscopy was performed with a PE Biosystems DE STR MALDI-TOF mass spectrometer (PerkinElmer Life and Analytical Sciences Inc.). The identified fragments were used for peptide mass matching by ProFound (25). The gene sequences of homologous proteins were used for BLAST searching against the $\mathrm{Hc}$ genesequence data at the Genome Sequencing Center at Washington University in St. Louis (26).

The putative gene encoding the identified protein was amplified from $\mathrm{Hc}$ to confirm its presence in the yeast and then cloned into Escherichia coli to determine whether the mAb to $H c$ could bind the recombinant protein. $H c$ RNA was prepared with TRIzol Reagent (Life Technologies Inc.) from yeast cells disrupted with a Mini-BeadBeater-8 (BioSpec Products Inc., Bartlesville, Oklahoma, USA). First-strand cDNA was generated by RT-PCR using $5 \mu \mathrm{g}$ of $\mathrm{Hc}$ RNA and SuperScript II RNase H-Reverse Transcriptase (Invitrogen Corp., Carlsbad, California, USA) according the manufacturer's directions with a Mastercycler gradient PCR (Eppendorf, Westbury, New York, USA). PCR was then 


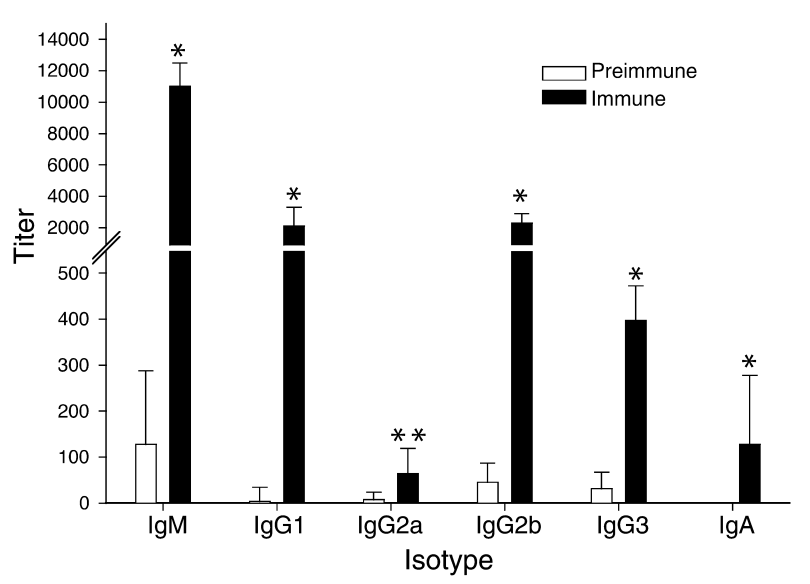

Figure 1

Whole-yeast-cell ELISA demonstrating the serological response to immunization with intact heat-killed $\mathrm{Hc}$. Preimmune serum was obtained prior to immunization. The hyperimmune serum was taken 2 weeks after the fourth immunization. The sera were serially diluted in blocking solution. For comparison of preimmune and immune sera for each isotype, ${ }^{*} P<0.01$ and ${ }^{*} P=0.018$ by Student's $t$ test. The results were from the mouse with the strongest immune response, but results were similar in all mice.

performed using $1 \mu \mathrm{g}$ of the cDNA in $50 \mu \mathrm{l}$ volume containing $5 \mathrm{U}$ of TaKaRa Taq polymerase (PanVera LLC, Madison, Wisconsin, USA), $10 \mathrm{mM}$ of each dNTP, $20 \mathrm{mM}$ Tris- $\mathrm{HCl}$ ( $\mathrm{pH} 8.4), 50 \mathrm{mM} \mathrm{KCl}, 50 \mathrm{mM} \mathrm{MgCl}$, and $10 \mu \mathrm{M}$ of each primer. The primers were prepared from the ends of the putative gene sequence with additional amino acids that facilitate cloning into the vector. The sense primer with an EcoRI site was 5'-TTAATGAATTCATATGCCACCAAAGGCC GCTGAG, and the antisense primer with a SalI site was 5'-TTAATGTCGACTTATTTGGCGGACGAGGAG. The reaction conditions were initial denaturation at $94^{\circ} \mathrm{C}$ for 2 minutes followed by 30 cycles at $94^{\circ} \mathrm{C}$ for 30 seconds, $50^{\circ} \mathrm{C}$ for 30 seconds, and $72^{\circ} \mathrm{C}$ for 1 minute. The gene product was sequenced with an Applied Biosystems model 377 DNA Sequencer (Foster City, California, USA).

The amplified cDNA of the $17-\mathrm{kDa}$ protein gene was digested with EcoRI and SalI (Invitrogen Corp.) and cloned into the EcoRI-SalI site of pGEX-KG (27). The resulting plasmid was transformed into $\mathrm{DH} 5 \alpha$ E. coli cells that were plated on Luria-Bertani (LB) agar with $100 \mu \mathrm{g} / \mathrm{ml}$ of ampicillin. To generate recombinant protein, a plasmid purified from a selected colony was transformed into E. coli, grown in LB medium with ampicillin, and then boiled for 5 minutes to lyse the bacteria. Western blot analysis was performed as described above. Western blot analysis was also done to assess whether an $\mathrm{Ab}$ response to the protein occurred during infection. After blocking, the recombinant protein electroblotted to nitrocellulose membranes was incubated with serum obtained before or 3 weeks after infection of C57BL/ 6 mice with $5 \times 10^{6} \mathrm{Hc}$. The blots were washed in TBST, incubated with GAM IgM/IgG conjugated to HRP, and then developed as described above.
Statistics. Statistical significance was determined using the Student's $t$ test, Kruskal-Wallis nonparametric ANOVA test (Primer; McGraw-Hill, New York, New York, USA), or log-rank analysis (SPSS Inc., Chicago, Illinois, USA), depending on the data.

\section{Results}

Generation of $m A b$ 's to Hc cell surface. Immunization of mice with killed $H c$ elicited IgM, IgG, and IgA reactive to $H c$ yeast as measured by whole-cell ELISA (Figure 1). $\mathrm{IgM}$ was the most prevalent isotype. From the spleen of an immunized mouse, three IgM- $\kappa$ hybridoma lines were generated (9C7, 5B8, and 3B9). No IgG isotype $\mathrm{mAb}$ 's were identified. Each of the three mAb's bound to Hc strain G217B and strain CIB 1980 yeast in a circumferential pattern on the cell surface by immunofluorescent assay. The mAb's to $H c$ did not bind $P$. brasiliensis, S. schenckii, S. cerevisiae, C. albicans, or C. neoformans yeast cells. Immunohistochemistry of infected $\mathrm{BALB} / \mathrm{c}$ lung tissue showed that the mAb's reacted with yeast cell walls (Figure 2a), establishing that the antigen is expressed during murine infection. Immunogold transmission electron microscopy confirmed that the $\mathrm{mAb}$ 's labeled antigen located in the cell wall (Figure $2 b)$. Labeling also occurred on the interior of the cell, which suggests that the antigen is formed intracellularly and transported to the cell wall. Notably, more
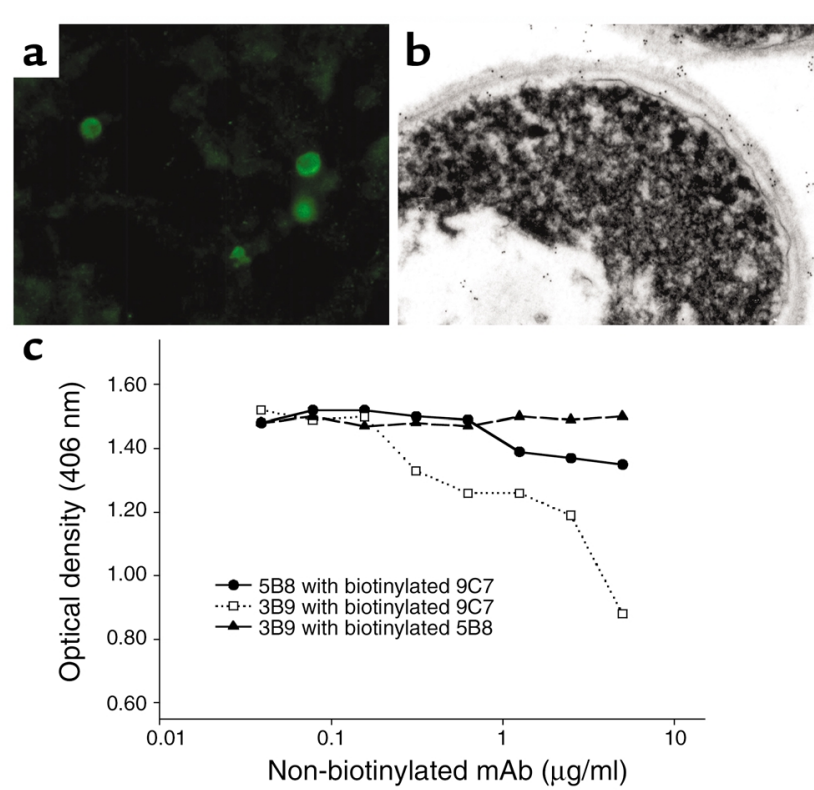

Figure 2

The mAb's react with $H_{c}$ yeast. (a) Immunofluorescence microscopy demonstrating labeling of $\mathrm{Hc}$ by $\mathrm{mAb} 9 \mathrm{C} 7$ in infected murine lung. Similar labeling was seen with mAb's 5B8 and 3B9. No binding occurred with control Ab's. (b) Immunogold transmission electron microscopy showing binding of $\mathrm{mAb} 9 \mathrm{C} 7$ to the cell wall of Hc. Binding also occurs intracellularly. Similar reactivity was seen with mAb's 5B8 and 3B9. No binding occurred with control Ab's. (c) Competition yeast cell ELISA using biotinylated and nonbiotinylated $\mathrm{mAb}$ 's to $H c$. The concentration of biotinylated mAb was kept constant, whereas the amount of the second mAb was serially diluted. The experiment was repeated with similar results. 
gold particles were identified using $\mathrm{mAb} 9 \mathrm{C} 7$ than using $\mathrm{mAb} 5 \mathrm{~B} 8$ or $3 \mathrm{~B} 9$. These results demonstrated that each of the three IgM mAb's to Hc bound antigen located on the cell surface of the yeast.

$m A b$ 's bind to at least two different epitopes. Competition ELISAs were performed to study mAb fine specificity. Binding of $\mathrm{mAb} 9 \mathrm{C} 7$ by $\mathrm{mAb} 3 \mathrm{~B} 9$ was inhibited at concentrations greater than $0.5 \mu \mathrm{g} / \mathrm{ml}$, in competition assays where the concentration of biotinylated $\mathrm{mAb} 9 \mathrm{C} 7$ was constant (Figure 2c). Competition was not observed when $\mathrm{mAb} 5 \mathrm{~B} 8$ was incubated with either $\mathrm{mAb} 3 \mathrm{~B} 9$ or 9C7. Hence, $\mathrm{mAb}$ 's 9C7 and 3B9 competed, whereas 5B8 did not compete. Competition does not necessarily indicate common epitope specificity, since IgMs can interfere with each other's binding through steric interference. However, absence of competition is de facto evidence of binding to different epitopes. Hence, $\mathrm{mAb}$ 5B8 and mAb's 9C7 and 3B9 bind to different epitopes, and mAb's 9C7 and 3B9 may bind to the same or spatially related epitopes.
Assays of direct $m A b$ effects. Incubation of the $\mathrm{Hc}$-binding mAb's with $H c$ did not result in cell lysis or permeabilization. CFUs were similar for $\mathrm{Hc}$ incubated with or without the protective mAb's (data not shown). Opsonization of $\mathrm{Hc}$ with the mAb's did not result in agglutination of the yeast cells. No alterations in the protein concentrations were detected in the supernatants from cells incubated with or without the $\mathrm{Hc}$-binding mAb's using the ThioGlo 1 assay (limit of detection, $10 \mathrm{nM}$ thiol-containing protein), indicating that there was no permeabilization of the fungus by the protective mAb's (data not shown). After 36 hours of growth, the number of yeast cells in media was significantly decreased in cultures where $100 \mu \mathrm{g} / \mathrm{ml} \mathrm{mAb} 9 \mathrm{C} 7$ was added, compared with cultures supplemented with control $\mathrm{mAb}$ (48 hours: $5.6 \times 10^{6}$ vs. $7.4 \times 10^{6}, P<0.001 ; 72$ hours: $7 \times 10^{6}$ vs. $\left.1.2 \times 10^{7}, P<0.001\right)$. No differences in growth were noted when $10 \mu \mathrm{g} / \mathrm{ml} \mathrm{mAb} 9 \mathrm{C} 7$ or either concentration of $\mathrm{mAb}$ 3B9 or 5B8 was used (data not shown).

Passive immunization reduces fungal burden and inflammation and prolongs survival. C57BL/6 mice given $\mathrm{Hc}$-binding
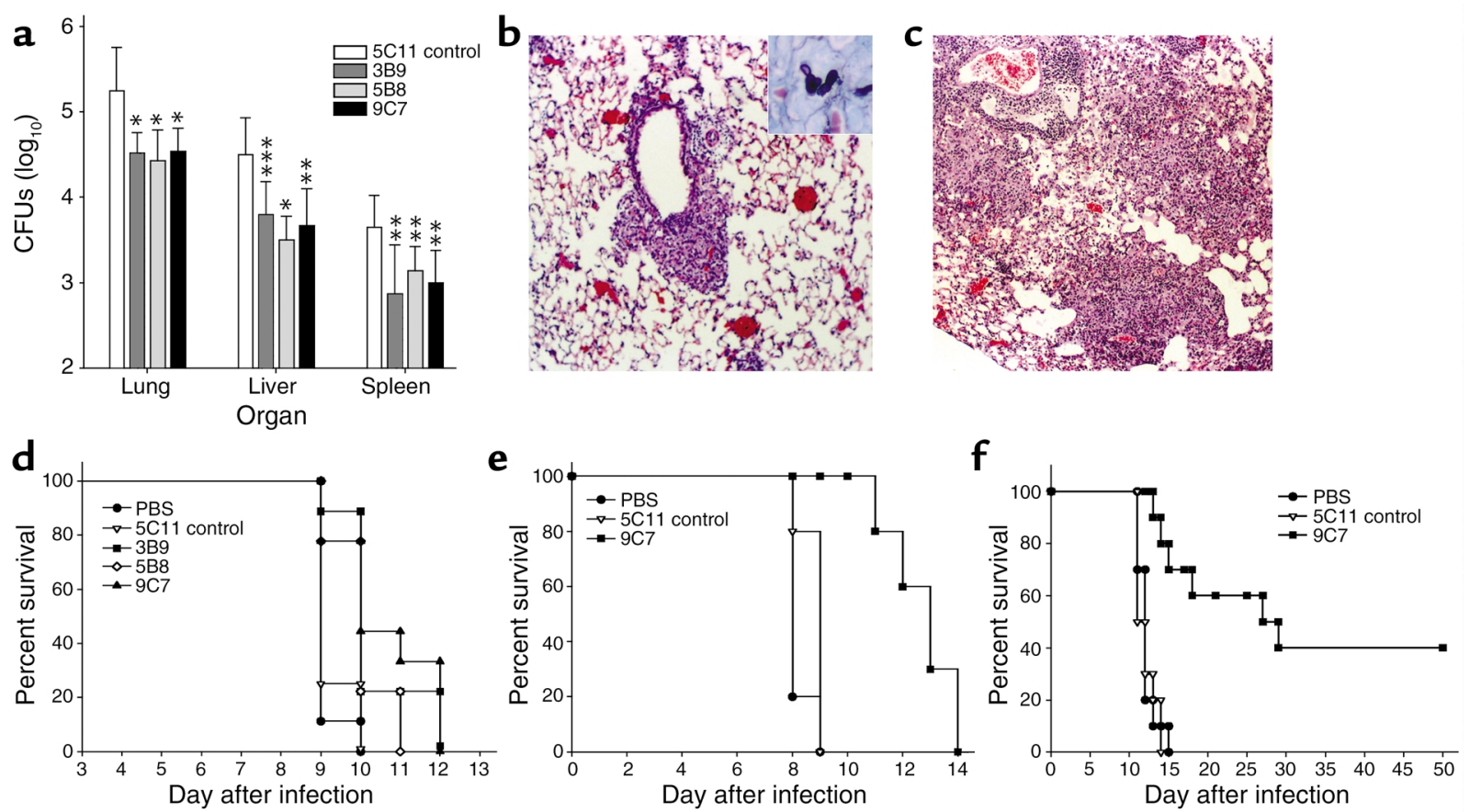

\section{Figure 3}

For the in vivo studies, ten mice were used for each condition studied in each experiment. Differences in fungal burden were analyzed by KruskalWallis test, and differences in survival were analyzed by log-rank test. The experiments were repeated at least twice, and similar results were obtained. (a) CFU determinations of $\mathrm{Hc} 14$ days after infection of C57BL/ 6 mice with $5 \times 10^{6}$ yeast. Bars are means of CFUs from four plates for each condition, and the error bars denote SD. The $P$ values were generated by Kruskal-Wallis test comparing the median CFUs for mAbtreated mice with those for mice that received mAb $5 C 11$ (control): ${ }^{*} P<0.001,{ }^{*} P<0.01,{ }^{*} * P=0.02$. The experiment was repeated with similar results. (b and c) Histology of lungs from C57BL/ 6 mice pretreated with protective and nonprotective $\mathrm{mAb}$ and infected with $5 \times 10^{6}$ yeast. (b) Representative image of lung from a mouse treated with protective $\mathrm{mAb} 9 \mathrm{C} 7$, showing peribronchiolar inflammation and intact alveoli. (c) The lungs of mice given control $\mathrm{mAb}$ had dense inflammatory infiltrates filling much of the alveoli. The original magnification was $\times 250$, and the samples were stained with $\mathrm{H} \& \mathrm{E}$. The inset in $\mathbf{b}$ shows $\mathrm{Hc}$ by Gomori's methenamine-silver staining. (d) $\mathrm{mAb}$ to $H c$ prolongs survival of lethally infected mice. Mice were pretreated with $100 \mu \mathrm{g}$ of mAb to $\mathrm{Hc}$, nonspecific mAb (5C11), or PBS and infected with $1.25 \times 10^{7}$ yeast. Compared with that of mice that received mAb $5 \mathrm{C} 11$ (control), survival was significantly prolonged with $\mathrm{mAb}$ to $\mathrm{Hc}(9 \mathrm{C} 7, P=0.002$; 3B9, $P=0.004 ; 5 B 8, P=0.007)$. (e) Preincubation of $\mathrm{mAb} 9 \mathrm{C} 7$ with $\mathrm{Hc}$ before lethal infection significantly prolonged survival compared with controls $(9 C 7, P<0.001)$. (f) Significant prolongation of the survival of lethally infected mice compared with controls $(P<0.001)$ was achieved by administration of $\mathrm{mAb} 9 \mathrm{C} 7$ before infection and treatment with subinhibitory concentrations of amphotericin $\mathrm{B}$. 

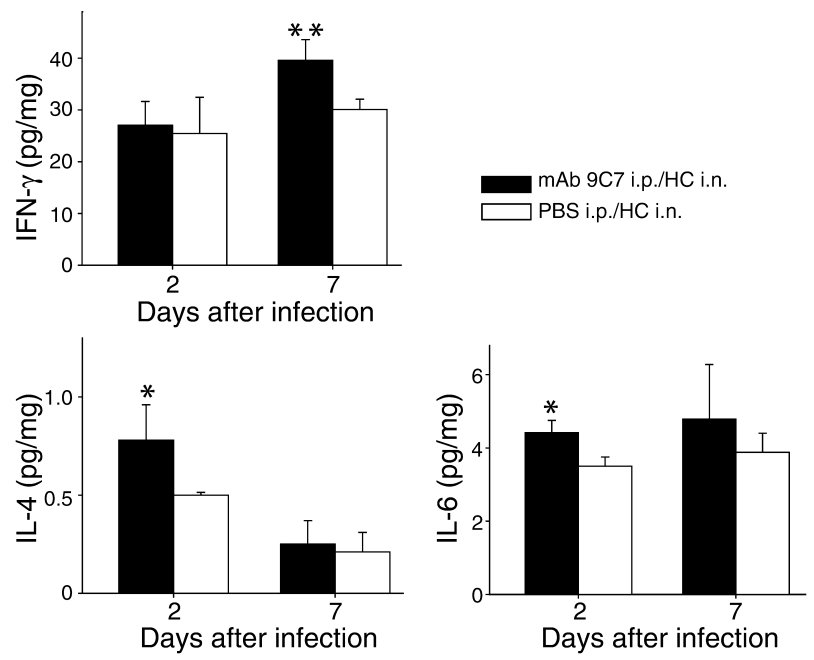

$\mathrm{mAb}$ prior to nonlethal intranasal infection with $5 \times 10^{6}$ yeast had significantly reduced average CFUs in the lungs, liver, and spleen compared with the control group (Figure 3a). BALB/c mice treated with $\mathrm{mAb} 9 \mathrm{C} 7$ or $5 \mathrm{~B} 8$ also had significant reductions in CFUs, but administration of $\mathrm{mAb} 3 \mathrm{~B} 9$ did not result in a significant reduction in fungal burden (data not shown).

Histological examination revealed that mice given $\mathrm{mAb}$ prior to $\mathrm{Hc}$ infection had an altered inflammatory response to infection. Mice given $\mathrm{Hc}$-binding $\mathrm{mAb}$ had less pulmonary inflammation (Figure $3 \mathrm{~b}$ ) than mice given non-Hc-binding mAb (Figure 3c). Even though $\mathrm{mAb} 3 \mathrm{~B} 9$ did not affect pulmonary fungal burden in $\mathrm{BALB} / \mathrm{c}$ mice, a greater decrease in inflammation was observed in the $\mathrm{mAb} 3 \mathrm{~B} 9$-treated mice than in control mice, albeit the reduction in inflammation with $3 \mathrm{~B} 9$ was less than with $5 \mathrm{~B} 8$ or 9C7. The inflammation in mice treated with mAb to $H c$ was generally localized adjacent to bronchioles, with the alveolar airspaces appearing intact. In contrast, diffuse dense pneumonia was evident in control mice. These studies demonstrated that administration of $\mathrm{Hc}$-binding $\mathrm{mAb}$ prior to infection with $H c$ reduced pulmonary CFUs and inflammation.

$\mathrm{C} 57 \mathrm{BL} / 6$ mice given $\mathrm{Hc}$-binding $\mathrm{mAb}$ prior to lethal infection $\left(2.5 \times 10^{7}\right.$ yeast $)$ survived significantly longer than mice given nonspecific mAb or PBS (Figure $3 \mathrm{~d}$ ). Although statistically significant, the prolongation of survival was relatively brief, only 1-2 days. Since serum IgM can be expected to have poor penetration into the alveolar fluid, we modified the experiment by coincubating $H c$ with $\mathrm{mAb}$ prior to infection. The average survival of mice infected with $H c$ preincubated with mAb 9C7 was significantly longer than that of control mice $(P<0.001$; Figure $3 e)$. In a second set of experiments, subinhibitory concentrations of amphotericin $\mathrm{B}$ given in conjunction with $\mathrm{mAb}$ to $\mathrm{Hc}$ significantly extended the survival of mice (Figure 3f). Whereas mice given nonspecific $\mathrm{Ab}$ were dead by day $14,40 \%$ of mice treated with $\mathrm{mAb} 9 \mathrm{C} 7$ and subin-

\section{Figure 4}

Cytokine expression in the lungs of mice in the presence or absence of mAb treatment. Mice were given mAb 9C7 or PBS intraperitoneally, followed by $\mathrm{Hc}$ or PBS intranasally. The cytokine levels were measured at days 2 and 7 postinfection. Values are normalized to total lung weight. Bars denote mean protein concentration, and error bars represent SD. $n=6$ for mouse groups that received mAb $9 C 7$ intraperitoneally plus Hc G217B intranasally (mAb 9C7 i.p./Hc i.n.) or PBS intraperitoneally plus Hc G217B intranasally (PBS i.p./Hci.n.). ${ }^{*} P=0.01,{ }^{*} P=0.04$ by Student's $t$ test.

hibitory concentrations of amphotericin $\mathrm{B}$ were alive at day $50(P<0.001)$. When mAb $5 \mathrm{~B} 8$ was combined with the antifungal drug, $30 \%$ of the infected animals were alive at day $50(P=0.004)$, and mAb 3B9 extended the survival of mice to day $29(P=0.04)$.

$m A b$ treatment alters cytokine and chemokine expression. At day 2 postinfection, lung tissue of infected mice treated with $\mathrm{mAb} 9 \mathrm{C} 7$ contained significantly higher quantities of IL-4 and IL- 6 than lung tissue of control mice (Figure 4). Administration of $\mathrm{mAb} 9 \mathrm{C7}$ also produced a statistically significant increase in IFN- $\gamma$ in the lungs of infected mice at day 7 (Figure 4). Ab administration did not affect the production of the other cytokines or chemokines. Additionally, no differences were noted between uninfected mice given mAb 9C7 or PBS.

$m A b$ to Hc promotes macrophage fungicidal activity in vitro. $\mathrm{Hc}$ yeast cells opsonized with mAb 9C7 were more avidly ingested by J774.16 cells than were cells incubated with isotype-matched control mAb or PBS (Figure 5a). The mAb-mediated increase in phagocytosis was significantly reduced when $C D 11 b, C D 18$, or both were blocked with specific Ab's (Figure 5a). Although Ab to CD11a and $\mathrm{CD} 11 \mathrm{c}$ reduced phagocytosis in controls, no reduction occurred when the yeast were opsonized with protective $\mathrm{mAb}$. There was no difference in phagocytosis of $H c$ with control $\mathrm{mAb}$ and $\mathrm{PBS}$.

The finding that the $\mathrm{mAb}$-dependent increase in phagocytosis was mediated through CR3 (CD11b/ CD18) was confirmed by studies with $\mathrm{CHO}$ cells expressing CR1, CR3, CR4, or LFA1 (Figure 5b). Phagocytosis of $\mathrm{Hc}$ opsonized with protective $\mathrm{mAb}$ was greatest with $\mathrm{CHO}$ cells transfected with $\mathrm{CR} 3$, and the phagocytic index was significantly greater than that from these cells incubated with yeast and control $\mathrm{mAb}$ $(P<0.001)$. The phagocytic indexes were lower with $\mathrm{CHO}$ cells, consistent with prior findings that the ingestion process in these cells is not as efficient as for murine macrophages (28). In summary, the protective mAb 9C7 promoted phagocytosis of $\mathrm{Hc}$ through CR3 in a complement-independent process.

The incorporation of $\left[{ }^{3} \mathrm{H}\right]$ leucine in $\mathrm{mAb} 9 \mathrm{C} 7-$ opsonized $H c$ was reduced by $54 \%$ compared with that in yeast incubated with control $\mathrm{mAb}(P<0.001$; Figure $5 \mathrm{c})$. There was no difference in the incorporation of radioactivity between yeast incubated with control $\mathrm{mAb}$ or PBS. Killing of intracellular $\mathrm{Hc}$ was measured by CFUs in the presence or absence of protective $A b$ grown with macrophage compared with culture in 
medium alone (Figure $5 \mathrm{~d}$ ). The growth of yeast incubated with mAb 9C7 in the presence of macrophage was reduced by approximately $30 \%$ compared with the growth of $\mathrm{Hc}$ in medium alone. In contrast, growth doubled for $\mathrm{Hc}$ incubated with nonspecific $\mathrm{mAb}$ or PBS in the presence of macrophage compared with yeast in medium alone. The results suggested that the intracellular growth of $\mathrm{Hc}$ was inhibited following phagocytosis of $H c$ opsonized with $\mathrm{mAb}$.

Identification of the protective antigen on $\mathrm{Hc}$. Immunoblots of cell wall proteins revealed that the three mAb's each bound to proteins of 17 and $34 \mathrm{kDa}$ (Figure 6a). This is noteworthy since the competition ELISAs detailed above (Figure 2c) demonstrated that the epitope recognized by $\mathrm{mAb} 5 \mathrm{~B} 8$ was different from the epitope or epitopes recognized by mAb's 9C7 and 3B9. Hence, the mAb's appeared to bind different epitopes on the same or a similar antigen. No binding was detected when the cell wall/cell membrane preparations were treated with proteinase $\mathrm{K}$ prior to Western blot analysis (data not shown). Treatment of these preparations with $\mathrm{N}$-glycosidase or sodium metaperiodate did not affect the reactivity of the $\mathrm{mAb}$ with the preparations (data not shown). Serial incubation of the cell wall/cell membrane preparations with DTT, Triton, CHAPS, and sodium carbonate significantly reduced the number of bands identified by Coomassie staining of Western gels, and the corresponding immunoblots reveal that the $\mathrm{Hc}$-binding mAb's bound only at $17 \mathrm{kDa}$ (Figure $6 \mathrm{~b}$ ). Hence, the $34-\mathrm{kDa}$ protein may be dimeric or have an associated anchor. Mass spectroscopy data on the 17 $\mathrm{kDa}$ protein recovered from the gel identified several fragments that were used for peptide mass matching by ProFound (25). Several high-probability sequences were identified, including histone $\mathrm{H} 2 \mathrm{~B}$ (protein ID no. 122046) of Aspergillus nidulans (probability 1, estimated $Z$ value 1.66). BLAST searching was performed using the sequence of the $A$. nidulans H2B gene (gene no. 55547) against the currently available $H c$ gene sequence at the Genome Sequencing Center at Washington University in St. Louis (26). The deduced amino acid sequences in $H c$ were within F_HCG217B.contig_p9135 in the histoplasma database. The sequence

\section{Figure 5}

of the cDNA generated from the PCR reactions and the protein encoded by the gene were identical to the predicted results (Figure $6 \mathrm{~d}$ ). The $17-\mathrm{kDa}$ protein had a $95 \%$ identity with $A$. nidulans histone $\mathrm{H} 2 \mathrm{~B}$, and significant homology with histone $\mathrm{H} 2 \mathrm{~B}$ sequences previously described in other fungi (Figure 6e). Western blot analysis demonstrated that the $\mathrm{Hc}$-binding mAb's reacted with the recombinant antigen, confirming that the histone-like antigen was indeed the molecule recognized (Figure $6 c$ ). Binding of immune serum $\mathrm{Ab}$ was detected at a 1:100 dilution, indicating the presence of a low level of $\mathrm{Ab}$ to the recombinant protein. No bind-
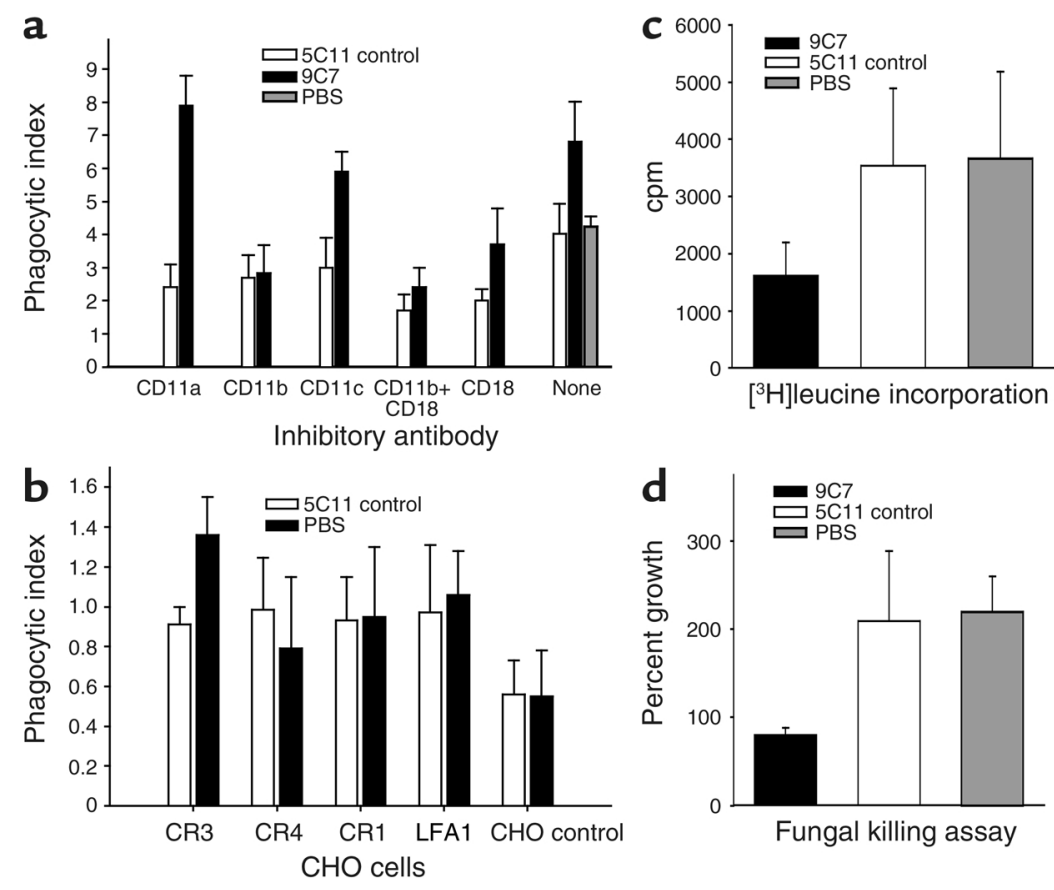

Intracellular fate of Hc. Black bars represent $100 \mu \mathrm{g} / \mathrm{ml}$ mAb 9C7, white bars 5 C11 isotype-matched control mAb, and gray bars PBS. Student's $t$ test was used to analyze the data in each panel. (a) Effect of IgM on Hc phagocytosis. Phagocytosis, by J774.16 macrophage-like cells, of $\mathrm{Hc}$ incubated with or without protective $\mathrm{mAb}$ in the presence or absence of mAb to CD11a, CD11b, CD11c, or CD18. Phagocytosis was performed without complement. Bars are the average of measurements from three wells (five fields each), and error bars denote SD. ${ }^{*} P<0.001$ comparing phagocytic index of $\mathrm{Hc}$ with $\mathrm{mAb} 9 \mathrm{C} 7$ or control mAb for each condition examined. ${ }^{*} P<0.001$ comparing phagocytic index of mAb $9 \mathrm{C} 7$ in the absence vs. the presence of complement receptor blockage. ${ }^{* *} P<0.001$ comparing mAb 9C7 and PBS. (b) Phagocytosis of $\mathrm{Hc}$ by $\mathrm{CHO}$ cells. Phagocytosis of $\mathrm{Hc}$ incubated with protective or nonspecific $\mathrm{mAb}$ in the presence of CHO cells expressing CR1, CR3, CR4, LFA1, or no receptor. The experiment was done without complement. Bars are the average of measurements from three wells (five fields each), and error bars denote SD. A significant difference was seen between mAb's in $\mathrm{CHO}$ cells expressing CR3 ( $\left.{ }^{*} P<0.001\right)$. (c) Effect of specific mAb on the growth of $\mathrm{Hc}$. The incorporation of $\left[{ }^{3} \mathrm{H}\right]$ leucine was significantly lower for $\mathrm{Hc}$ phagocytosed by J774.16 cells in the presence of mAb 9 C7 compared with controls $\left({ }^{*} P<0.001\right)$. Bars are the average of measurements from five wells, and error bars denote SD. (d) $H_{c}$ growth was inhibited and killing occurred when the yeast was phagocytosed by 177416 macrophages in the presence of protective mAb. Yeast cells replicated when phagocytosed in the absence of protective $\mathrm{mAb}$. The difference in percentage growth between yeast incubated with mAb $9 C 7$ and controls was significant $\left({ }^{*} P<0.001\right)$. Bars are the average of measurements from five plates, and error bars denote SD. Each experiment was repeated at least once, and similar results were obtained. 


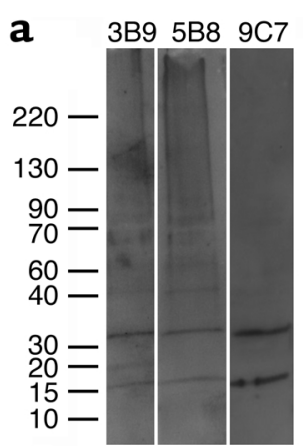

b

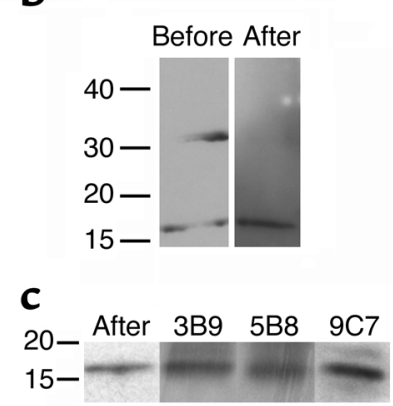

T. TATAAGTACTCGCCCCCCACCAGCTTCCTCGTCGCGACTCTTGTTCTTTTCTTCTTCCTCTCCATATCCCG CTAACAACCGTCCCCCGTCGTTCATCTCCGCACGTCCACGTTTGTGTGTTTATTCTCACTCCGCATTCGCC TCTACCAACTTTATTTTTTTAATTAAAAATCAAACAACCAAATCACAATGCCACCAAAGGCCGCTGAGAAG $\begin{array}{lllllllll}M & P & P & K & A & A & E & K\end{array}$

AAGCCCTCCACTGCTGGCAAAGCCCCAGCTGGCAAAGCTCCTGAGAAGAAGGAGGCCGGCAAGAAGACCAC $\begin{array}{lllllllllllllllllllllllll}K & P & S & T & A & G & K & A & P & A & G & K & A & P & E & K & K & E & A & G & K & K & T & \end{array}$ TGCTGCTGGTGGTGAGAAGAAAAAGCGATCCAAGACCAGAAAAGAGACCTACTCCTCCTACATCTACAAAG $\begin{array}{lllllllllllllllllllllll}A & A & G & G & E & K & K & K & R & S & K & T & R & K & E & T & Y & S & S & Y & I & Y & K\end{array}$ GTATGTTGTAAATTTCCCTGTCGCTGCTCCCTCTCACCCATCAATCAAAAAATCTCTCTATTTTGACGCGA TGGAAGCGTGCTAACGCGTTTTTCTTTTCTTTTGTCCTTAGTCCTCAAGCAAGTCCACCCAGATACAGGTA $\begin{array}{llllllllllllll}V & L & K & Q & V & H & P & D & T & G\end{array}$ TCTCAAACCGCGCCATGTCTATTCTCAATTCCTTCGTCAATGGTATGTCGCCTCATTCATGTGTCCCGTAG $\begin{array}{lllllllllllllllll}I & S & \mathbf{N} & \mathbf{R} & \mathbf{A} & \mathbf{M} & \mathbf{S} & \text { I } & \text { L } & \mathbf{N} & \mathbf{S} & \mathbf{F} & \mathrm{V} & \mathbf{N}\end{array}$

GAGTCATAACTAATTCTTCCCACAGATATCTTTGAGCGTGTCGCCACTGAAGCCTCCAAGCTTGCTGCATA

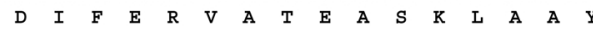
CAACAAGAAATCCACCATCTCTTCCCGAGAAATTCAGACTTCGTAAGTTTGCTCGTTCCGCAATACAATCC $\begin{array}{lllllllllllllllll}N & K & K & S & T & I & S & S & R & E & I & Q & T\end{array}$ AGCACATCGCATCACTAACAAACCCCCTTTCACAGCGTGAGACTCATCCTGCCAGGTGAACTTGCCAAGCA $\begin{array}{lllllllllllllll}S & V & R & \text { L } & \text { I } & \text { L } & \text { P } & \text { G } & \text { E } & \text { L } & \text { A } & K & \text { K }\end{array}$

TGCCGTCTCTGAAGGTACAAAGGCTGTCACCAAGTACTCCTCGTCCGCCAAATAA

$\begin{array}{llllllllllllllllll}\mathbf{A} & \mathbf{V} & \mathbf{S} & \mathbf{E} & \mathbf{G} & \mathbf{T} & \mathbf{K} & \mathbf{A} & \mathbf{V} & \mathbf{T} & \mathbf{K} & \mathbf{Y} & \mathbf{S} & \mathbf{S} & \mathbf{S} & \mathbf{A} & \mathbf{K} & \text { stop }\end{array}$
Histo.
Asperg
Rosel1.
Neurosp.
Saccharo.
Agaricus
1 MPPKAAEKKP-STGGKAPAGKAPAEKKEAGKKTAAAASGEKKKRGKTRKETYSSYIYKVLK
1 MPPKAADKKP-AA - -KAPVASKAPEKKDAGKKTA--STGEKKKRTKARRETYSSYIYKVLK
1 MPPKPADKKP-ASKAPATASKAP-EKKDAGKKTA--ASGDKKKRTKARKETYSSYIYKVLK
1 MS-SAAEKK- - - - - - PASKAPAEKKPAAKKTSTSVDG--KKRSKVRKETYSSYIYKVLK
5 PASTAGKAPASTASKAPVKSDAAKTASKSKVSSGA-DGEKKKRKKTRKETYSSYIYKVLK
Histo.
Asperg.
Rosel1.
Neurosp.
Saccharo.
Agaricus
Histo.
Asperg
Rosel1.
Neurposp.
Saccharo.
Agaricus
59 QVHPDTGISNRAMSILNSFVNDIFERVATEASKLAAYNKKSTISSREIQTSVRLILPGEL
61 QVHPDTGISTRAMSILNSFVNDIFERVATEASKLAAYNKKSTISSREIQTSVRLILPGEL
57 QVHPDTGISNRAMSILNSFVNDIFERVATEASKLAAYNKKSTISSREIQTSVRLILPGEI
58 OVHPDTGISNRAMSILNSFVNDIFERVATEASKLAAYNKKSTISSREIQTSVRLILPGEI
51 QTHPDTGISQKSMSILNSFVNDIFERIATEASKLAAYNKKSTISAREIQTAVRLILPGEI
64 QVHPDTGISNKAMAILNSFVNDIFERIATEASKLASYSKKSTISSREIQTSVRLILPGEL
119 AKHAVSEGTKAVTKYSSSAK
121 AKHAVSEGTKAVTKYSSSAK
117 AKHAVSEGTKAVTKYSSSTK
118 AKHAVSEGTKAVTKYSSSTK
111 AKHAVSEGTRAVTKYSSS
124 AKHAISEGTKSVTKFSSGGK
Aspegillus nidulans: $95.0 \%$ identity in 140 residues overlap Rosellinia necatrix: 89.9\% identity in 139 residues overlap Neurospora crassa: $88.4 \%$ identity in 138 residues overlap
Saccharomyces cerevisiae: 78.1\% identity in 128 residues overlap
Agaricus bisporus: $75.5 \%$ identity in 139 residues overlap

1 MPPKAAEKKP-STAGKAPAGKAP-EKKEAGKKTTAAG-GEKKKRSKTRKETYSSYIYKVLK

\section{Figure 6}

Western blot analysis of mAb binding to $\mathrm{Hc}$ surface protein. (a) Immunoblots of cell wall proteins demonstrating binding of mAb's 3B9, $5 \mathrm{~B} 8$, and $9 \mathrm{C} 7$ to proteins at 17 and $34 \mathrm{kDa}$. (b) Binding of mAb $9 \mathrm{C} 7$ to $\mathrm{Hc}$ surface proteins before and after serial treatment with $1 \mathrm{mM}$ DTT, 1\% Triton, $10 \mathrm{mM} \mathrm{CHAPS}$, and $100 \mathrm{mM}$ sodium carbonate, $\mathrm{pH} 10$. (c) Binding of mAb 9C7 to Hc proteins after serial treatment and reactivity of the $\mathrm{Hc}$-binding $\mathrm{mAb}$ 's to recombinant protein (second through fourth lanes). (d) Gene sequence and deduced amino acid sequence of the protein recognized by the mAb to $\mathrm{Hc}$. (e) The protein sequence is compared with that of histone $\mathrm{H} 2 \mathrm{~B}$ sequences reported in other fungi. These sequence data are available from GenBank/EMBL/DDBJ under accession no. AY316539.

ing occurred with preimmune serum or dilutions of immune serum greater than 1:100.

\section{Discussion}

The data presented here demonstrate that mAb's to $\mathrm{Hc}$ can modify the course of experimental murine histoplasmosis. The antigen recognized by the protective mAb's is a histone $\mathrm{H} 2 \mathrm{~B}-$ like protein. Although histones are commonly associated with DNA, the presence of histones on cell surfaces has been described in both eukaryotic and prokaryotic cells. In particular, histone $\mathrm{H} 2 \mathrm{~B}$ is present on the cell surface of leukocytes (29), T cells (30-34), B cells (35), and a human lung carcinoma cell line (36). Extracellular histones can stimulate lymphoid cell proliferation and Ig synthesis (37). An interesting consequence of this polyclonal activation of B cells is that lupus Ab's can bind cell surface histones with subsequent formation of immune complexes $(38,39)$. Mycobacterium leprae, an obligate intra- cellular pathogen, uses a histone-like protein in the binding of laminin on peripheral nerves (40-42), which facilitates invasion of the Schwann cells $(42,43)$. Similarly, Mycobacterium smegmatis produces a histone-like protein that is involved in binding to laminin on human pneumocytes and macrophages (44). Our observation that $H c$ expresses a histone-like protein on the surface is consistent with findings from other organisms. Furthermore, the association of histonelike proteins with mycobacterial attachment and virulence provides a precedent for interpreting our results. Passive immunization with $\mathrm{mAb}$ to a surface histonelike protein of $\mathrm{Hc}$ reduced fungal burden, diminished inflammation, and prolonged survival. Although the administration of $\mathrm{Hc}$-binding $\mathrm{mAb}$ prior to infection significantly increases survival of lethally infected mice, the efficiency of IgM-mediated phagocytosis must be interpreted in the context of the lung's limitations with respect to IgM function $(28,45)$. Lung macrophages 
express low levels of CR3, which our work shows is the opsonic receptor for $\mathrm{Hc}$ IgM-mediated phagocytosis. Although an IgM Fc receptor has been reported in peritoneal macrophages (46-49), there is no evidence for an Fc receptor on pulmonary macrophages, and it is unclear whether the putative $\mathrm{Fc}$ receptor on peritoneal macrophages functions in a manner similar to that of IgG Fc receptors. IgM is primarily limited to the serum compartment, and penetration into alveolar spaces can be expected to occur at only a fraction of serum levels. Hence, the observation that direct opsonization of $\mathrm{Hc}$ by preincubation with specific $\mathrm{mAb}$ provided greater prolongation of survival can be interpreted in the context of higher efficacy as a consequence of the maximization of $\mathrm{Ab}$ interactions with the pulmonary phagocytic cells. Furthermore, we found that the administration of the mAb significantly improved the efficacy of antifungal therapy with subinhibitory concentrations of amphotericin B. In addition to its antifungal effects, amphotericin $B$ can act as an immunomodulator (50). In C. neoformans, subinhibitory concentrations of amphotericin B can affect fungal cell charge and morphology, resulting in increased phagocytosis of yeast by macrophages (51). In histoplasmosis, subinhibitory concentrations of amphotericin B can act in an additive fashion with GM-CSF to protect mice lethally infected with $\mathrm{Hc}$ by stimulating nonadherent leukocytes to inhibit yeast cell growth (18).

The current paradigm for host control of histoplasmosis is based on activation of cellular immunity (52), since, in the absence of intact cellular immunity, progressive disease with dissemination occurs (12). Our observations do not challenge the existing paradigm that cellular immunity is central for controlling histoplasmosis; rather, they indicate that some Ab's can also mediate protection when used as immunoprophylaxis. The finding that immune serum binds to the $\mathrm{Hc}$ histone-like protein indicates that the immune system recognizes the protein during infection, but the low level of $A b$ present in serum suggests that it is not an immunodominant antigen. $\mathrm{Hc}$ immunity is characterized by the development of a brisk cytokine response with rapid increases in IL-12 levels in the first days after infection followed by increased levels of IFN- $\gamma$ (52). In our studies, mice given protective mAb had significantly higher levels of IFN- $\gamma$ compared with controls, though IL-12 levels were similar. Protective mAb also increased production of IL-4, which is consistent with the reduction in inflammatory cells seen in infected tissues. Administration of IL- 4 can protect mice against the deleterious effects of anti-IL-12 (13). Interestingly, administration of Ab to IL-4 has also been reported to decrease survival of infected mice (53). Although IL-4 production increased, IL-10 was not affected, which is consistent with previous findings that transcription of genes encoding IL- 10 does not occur in murine histoplasmosis (52). The binding of nucleosomes by $\mathrm{T}$ cells can stimulate the release of
IL-6 (54). The Hc-binding mAb's may enhance the interactions of the histone-like protein and $T$ cells. In histoplasmosis, profuse inflammatory responses can be detrimental, as illustrated by mediastinal fibrosis. The cytokine changes associated with mAb administration may reflect a more intense Th1-like response, as manifested by higher IFN- $\gamma$ levels detected at day 7 and moderation of early inflammatory-mediated damage by higher IL-4 levels detected at day 2 .

The role of phagocytic cells in histoplasmosis is complex. Macrophages are the primary effector cells in host resistance to $H c$. However, they may initially serve as a protective environment for the fungus in the lung. In the absence of $\mathrm{Ab}$ or complement, $\mathrm{Hc}$ hsp60 binds to CR3 receptors on macrophages, is phagocytosed, and replicates intracellularly $(20,55)$. Ingested $H c$ survives in the phagolysosomes of macrophages by maintaining a $\mathrm{pH}$ of about 6.5 in the vacuole $(56,57)$ and, in some instances, inhibiting phagolysosomal fusion (57). Interestingly, studies with human peripheral blood have revealed that activated monocytes bind extracellular histones (58). Experiments with Ab's to CD11a, CD11b, CD11c, and CD18 suggest that increased phagocytosis with mAb to $\mathrm{Hc}$ depends primarily on $\mathrm{CD} 11 \mathrm{~b}$ and $\mathrm{CD} 18$. The studies with $\mathrm{CHO}$ cells expressing CR receptors similarly indicate that the increase in phagocytosis seen with opsonized yeast occurs via the CR3 receptor (CD11b/CD18). Ingested yeast opsonized with $\mathrm{Hc}$-binding $\mathrm{mAb}$ had reduced growth and could be killed. The mAb's did not cause agglutination or direct toxicity to the fungus. The delay in growth of $\mathrm{Hc}$ in the presence of cell wall-binding $\mathrm{mAb}$ may be due to direct interference with the biosynthesis and organization of the cell wall, which is a mechanism proposed for mAb's to cell wall constituents in C. neoformans $(59,60)$. The finding that IgM promoted phagocytosis through CR3 independently of complement is reminiscent of a recent report that specific IgM to C. neoformans promoted phagocytosis of that fungus by facilitating complement-independent polysaccharide-CR3 interactions (28).

Disseminated histoplasmosis occurs with increased frequency in individuals with impaired immunity, particularly in patients with AIDS. Currently available medications for systemic fungal infections often fail to work in the setting of impaired immunity, and many AIDS patients require lifelong prophylaxis to prevent recurrent disease. Vaccine development in $\mathrm{Hc}$ has focused on inducing cellular responses to the fungus (61-63). The histone-like protein could be combined with previously identified protective antigens to generate a vaccine that may produce a beneficial cellular and humoral response to Hc. Although vaccine development for $\mathrm{Hc}$ is an exciting area of research (64), vaccination may not be effective in immunocompromised individuals. Hence, it is conceivable that this population may benefit most from passive therapy with specific mAb to $H c$. Combination of a $\mathrm{mAb}$ with antifungal therapy is currently being stud- 
ied in a clinical trial for treatment of cryptococcosis in patients with AIDS (16), and combined therapy is considered by several mycology experts to be a valid approach to improving current antifungal regimens $(65,66)$. Since amphotericin B is usually used for initial treatment of histoplasmosis, the addition of $\mathrm{mAb}$ to therapy should be considered in future studies. Future investigations of protective $\mathrm{mAb}$ may reveal additional important insights into the pathogenesis of histoplasmosis and $\mathrm{Ab}$ function against $\mathrm{Hc}$ and, perhaps, other intracellular pathogens.

\section{Acknowledgments}

J.D. Nosanchuk is supported in part by NIH grant AI52733 and an Albert Einstein College of Medicine Center for AIDS Research grant. J.N. Steenbergen is supported by NIH training grant T32GM 07491. G.S. Deepe, Jr., is supported by grants AI-34361 and AI42747 from the NIH and by a Merit Review from the Department of Veterans Affairs. A. Casadevall is supported by NIH Awards AI-33774, AI-13342, AI-52733, and HL-59842. The authors gratefully acknowledge Stephanie Tucker, George Orr, and the Laboratory for Macromolecular Analysis and Proteomics at Albert Einstein College of Medicine for assistance in the identification of the $17-\mathrm{kDa}$ protein. The Laboratory for Macromolecular Analysis and Proteomics is supported in part by the Albert Einstein Comprehensive Cancer Center (grant CA13330) and the Diabetes Research and Training Center (grant DK20541).

1. Cano, M.V., and Hajjeh, R.A. 2001. The epidemiology of histoplasmosis: a review. Semin. Respir. Infect. 16:109-118.

2. Retallack, D.M., and Woods, J.P. 1999. Molecular epidemiology, pathogenesis, and genetics of the dimorphic fungus Histoplasma capsulatum. Microbes Infect. 1:817-825.

3. Bradsher, R.W. 1996. Histoplasmosis and blastomycosis. Clin. Infect. Dis. 22(Suppl. 2):S102-S111.

4. Graybill, J.R. 1988. Histoplasmosis and AIDS. J. Infect. Dis. 158:623-626.

5. Wheat, L.J., et al. 1990. Disseminated histoplasmosis in the acquired immune deficiency syndrome: clinical findings, diagnosis and treatment, and review of the literature. Medicine (Baltimore). 69:361-374.

6. Wheat, J. 1996. Histoplasmosis in the acquired immunodeficiency syndrome. Curr. Top. Med. Mycol. 7:7-18.

7. Hajjeh, R.A., et al. 2001. Multicenter case-control study of risk factors for histoplasmosis in human immunodeficiency virus-infected persons. Clin. Infect. Dis. 32:1215-1220.

8. Wheat, L.J., et al. 2000. Factors associated with severe manifestations of histoplasmosis in AIDS. Clin. Infect. Dis. 30:877-881.

9. Casadevall, A. 1998. Antibody-mediated protection against intracellular pathogens. Trends Microbiol. 6:102-107.

10. Chandler, J.W., Jr., Smith, T.K., Newberry, W.M., Jr., Chin, T.D., and Kirkpatrick, C.H. 1969. Immology of the mycoses. II. Characterization of the immunoglobulin and antibody responses in histoplasmosis. J. Infect. Dis. 119:247-254.

11. Tewari, R.P., Sharma, D., Solotorovsky, M., Lafemina, R., and Balint, J. 1977. Adoptive transfer of immunity from mice immunized with ribosomes or live yeast cells of Histoplasma capsulatum. Infect. Immun. 15:789-795.

12. Allendorfer, R., Brunner, G.D., and Deepe, G.S., Jr. 1999. Complex requirements for nascent and memory immunity in pulmonary histoplasmosis. J. Immunol. 162:7389-7396.

13. Allendoerfer, R., Biovin, G.P., and Deepe, G.S., Jr. 1997. Modulation of immune responses in murine pulmonary histoplasmosis. J. Infect. Dis. 175:905-914.

14. Rosas, A.L., et al. 2000. Synthesis of polymerized melanin by Cryptococcus neoformans in infected rodents. Infect. Immun. 68:2845-2853.

15. Glatman-Freedman, A., Martin, J.M., Riska, P.F., Bloom, B.R., and Casadevall, A. 1996. Monoclonal antibodies to surface antigens of Mycobacterium tuberculosis and their use in a modified enzyme-linked immunosorbent spot assay for detection of mycobacteria. J. Clin. Microbiol. 34:2795-2802.

16. Casadevall, A., et al. 1998. Characterization of a murine monoclonal antibody to Cryptococcus neoformans polysaccharide that is a candidate for human therapeutic studies. Antimicrob. Agents Chemother. 42:1437-1446.

17. McCormack, F.X., et al. 2003. Macrophage-independent fungicidal action of the pulmonary collectins. J. Biol. Chem. 278:36250-36256.

18. Deepe, G.S., Jr., and Gibbons, R. 2000. Recombinant murine granulocyte-macrophage colony-stimulating factor modulates the course of pulmonary histoplasmosis in immunocompetent and immunodeficient mice. Antimicrob. Agents Chemother. 44:3328-3336.

19. Chan, J., Xing, Y., Magliozzo, R.S., and Bloom, B.R. 1992. Killing of virulent Mycobacterium tuberculosis by reactive nitrogen intermediates produced by activated murine macrophages. J. Exp. Med. 175:1111-1122.

20. Newman, S.L., Bucher, C., Rhodes, J., and Bullock, W.E. 1990. Phagocytosis of Histoplasma capsulatum yeasts and microconidia by human cultured macrophages and alveolar macrophages. Cellular cytoskeleton requirement for attachment and ingestion. J. Clin. Invest. 85:223-230.

21. Newman, S.L., Gootee, L., Brunner, G., and Deepe, G.S., Jr. 1994. Chloroquine induces human macrophage killing of Histoplasma capsulatum by limiting the availability of intracellular iron and is therapeutic in a murine model of histoplasmosis. J. Clin. Invest. 93:1422-1429.

22. Gomez, A.M., Rhodes, J.C., and Deepe, G.S., Jr. 1991. Antigenicity and immunogenicity of an extract from the cell wall and cell membrane of Histoplasma capsulatum yeast cells. Infect. Immun. 59:330-336.

23. Printen, J.A., and Sprague, G.F., Jr. 1994. Protein-protein interactions in the yeast pheromone response pathway: Ste $5 \mathrm{p}$ interacts with all members of the MAP kinase cascade. Genetics. 138:609-619.

24. Fernandez, J., Gharahdaghi, F., and Mische, S.M. 1998. Routine identification of proteins from sodium dodecyl sulfate-polyacrylamide gel electrophoresis (SDS-PAGE) gels or polyvinyl difluoride membranes using matrix assisted laser desorption/ionization-time of flight-mass spectrometry (MALDI-TOF-MS). Electrophoresis. 19:1036-1045.

25. ProFound. http://prowl.rockefeller.edu/cgi-bin/ProFound.

26. Genome Sequencing Center. Washington University in St. Louis, School of Medicine, St. Louis, Missouri, USA. http://genome.wustl.edu/.

27. Guan, K.L., and Dixon, J.E. 1991. Eukaryotic proteins expressed in Escherichia coli: an improved thrombin cleavage and purification procedure of fusion proteins with glutathione S-transferase. Anal. Biochem. 192:262-267.

28. Taborda, C.P., and Casadevall, A. 2001. Immunoglobulin M efficacy against Cryptococcus neoformans: mechanism, dose dependence, and prozone-like effects in passive protection experiments. J. Immunol. 166:2100-2107.

29. Rekvig, O.P., Muller, S., Briand, J.P., Skogen, B., and Van Regenmortel, M.H. 1987. Human antinuclear autoantibodies crossreacting with the plasma membrane and the N-terminal region of histone H2B. Immunol. Invest. 16:535-547.

30. Ojcius, D.M., Muller, S., Hasselkus-Light, C.S., Young, J.D., and Jiang, S. 1991. Plasma membrane-associated proteins with the ability to partially inhibit perforin-mediated lysis. Immunol. Lett. 28:101-108.

31. Watson, K., et al. 1995. Extra-nuclear location of histones in activated human peripheral blood lymphocytes and cultured T cells. Biochem. Pharmacol. 50:299-309.

32. Shaunak, S., et al. 1994. Infection by HIV-1 blocked by binding of dextrin 2-sulphate to the cell surface of activated human peripheral blood mononuclear cells and cultured T-cells. Br. J. Pharmacol. 113:151-158.

33. Watson, K., Gooderham, N.J., Davies, D.S., and Edwards, R.J. 1999. Nucleosomes bind to cell surface proteoglycans. J. Biol. Chem. 274:21707-21713.

34. Khan, I.U., Wallin, R., Gupta, R.S., and Kammer, G.M. 1998. Protein kinase A-catalyzed phosphorylation of heat shock protein 60 chaperone regulates its attachment to histone $2 \mathrm{~B}$ in the $\mathrm{T}$ lymphocyte plasma membrane. Proc. Natl. Acad. Sci. U. S. A. 95:10425-10430.

35. Mecheri, S., Dannecker, G., Dennig, D., Poncet, P., and Hoffmann, M.K. 1993. Anti-histone autoantibodies react specifically with the B cell surface. Mol. Immunol. 30:549-557.

36. Bilozur, M.E., and Biswas, C. 1990. Identification and characterization of heparan sulfate-binding proteins from human lung carcinoma cells. J. Biol. Chem. 265:19697-19703.

37. Bell, D.A., Morrison, B., and VandenBygaart, P. 1990. Immunogenic DNA-related factors. Nucleosomes spontaneously released from normal murine lymphoid cells stimulate proliferation and immunoglobulin synthesis of normal mouse lymphocytes. J. Clin. Invest. 85:1487-1496

38. Kubota, T., Kanai, Y., and Miyasaka, N. 1990. Interpretation of the cross-reactivity of anti-DNA antibodies with cell surface proteins: the role of cell surface histones. Immunol. Lett. 23:187-193.

39. Koutouzov, S., et al. 1996. Binding of nucleosomes to a cell surface receptor: redistribution and endocytosis in the presence of lupus antibodies. Eur. J. Immunol. 26:472-486. 
40. Pessolani, M.C., Hunter, S.W., and Brennan, P.J. 1993. Relationship between host histones and armadillo-derived Mycobacterium leprae. Int. J. Lepr. Other Mycobact. Dis. 61:381-388.

41. Marques, M.A.M., et al. 2001. Further biochemical characterization of Mycobacterium leprae laminin-binding proteins. Braz. J. Med. Biol. Res. 34:463-470.

42. Marques, M.A.M., et al. 2000. Bacterial and host-derived cationic proteins bind a2-laminins and enhance Mycobacterium leprae attachment to human Schwann cells. Microbes Infect. 2:1407-1417.

43. Shimoji, Y., Ng, V., Matsumura, K., Fischetti, V.A., and Rambukkana, A. 1999. A 21-kDa surface protein of Mycobacterium leprae binds peripheral nerve laminin-2 and mediates Schwann cell invasion. Proc. Natl. Acad. Sci. U. S. A. 96:9857-9862.

44. Pethe, K., et al. 2001. Mycobacterium smegmatis laminin-binding glycoprotein shares epitopes with Mycobacterium tuberculosis heparin-binding haemagglutinin. Mol. Microbiol. 39:89-99.

45. Taborda, C.P., and Casadevall, A. 2002. CR3 (CD11b/CD18) and CR4 (CD11c/CD18) are involved in complement-independent antibodymediated phagocytosis of Cryptococcus neoformans. Immunity. 16:791-802.

46. Isaac, L., and Mariano, M. 1988. The IgM receptor in mouse peritoneal macrophages. Clin. Exp. Immunol. 72:516-520.

47. Uher, F., Dobronyi, I., and Gergel, J. 1981. IgM-Fc receptor-mediated phagocytosis of rat macrophages. Immunology. 42:419-425.

48. Medgyesi, G.A., Foris, G., Fust, G., and Bazin, H. 1984. Regulation of Fc mu receptor-mediated functions of resident and provoked peritoneal macrophages. Immunobiology. 167:293-300.

49. Shibuya, A., et al. 2000. Fc alpha/mu receptor mediates endocytosis of IgM-coated microbes. Nat. Immunol. 1:441-446.

50. Nosanchuk, J.D., and Casadevall, A. 1999. Amphotericin B: activity beyond fungal cell sterols. Recent Research Developments Antimicrobial Agents \& Chemotherapy. 3:7-15.

51. Nosanchuk, J.D., Cleare, W., Franzot, S.P., and Casadevall, A. 1999. Amphotericin B and fluconazole affect cellular charge, macrophage phagocytosis, and cellular morphology of Cryptococcus neoformans at subinhibitory concentrations. Antimicrob. Agents Chemother. 43:233-239.

52. Cain, J.A., and Deepe, G.S., Jr. 1998. Evolution of the primary immune response to Histoplasma capsulatum in murine lung. Infect. Immun. 66:1473-1481.

53. Zhou, P., et al. 1995. IL-12 prevents mortality in mice infected with
Histoplasma capsulatum through induction of IFN-gamma. J. Immunol. 155:785-795

54. Hefeneider, S.H., et al. 1992. Nucleosomes and DNA bind to specific cell-surface molecules on murine cells and induce cytokine production. Clin. Immunol. Immunopathol. 63:245-251.

55. Bullock, W.E., and Wright, S.D. 1987. Role of the adherence-promoting receptors, CR3, LFA-1, and p150,95, in binding of Histoplasma capsulatum by human macrophages. J. Exp. Med. 165:195-210.

56. Eissenberg, L.G., Goldman, W.E., and Schlesinger, P.H. 1993. Histoplasma capsulatum modulates the acidification of phagolysosomes. J. Exp. Med. 177:1605-1611.

57. Strasser, J.E., et al. 1999. Regulation of the macrophage vacuolar ATPase and phagosome-lysosome fusion by Histoplasma capsulatum. J. Immunol. 162:6148-6154.

58. Emlen, W., Holers, V.M., Arend, W.P., and Kotzin, B. 1992. Regulation of nuclear antigen expression on the cell surface of human monocytes. J. Immunol. 148:3042-3048.

59. Rosas, A.L., Nosanchuk, J.D., and Casadevall, A. 2001. Passive immunization with melanin-binding monoclonal antibodies prolongs survival of mice with lethal Cryptococcus neoformans infection. Infect. Immun. 69:3410-3412

60. Rodrigues, M.L., et al. 2000. Human antibodies against a purified glucosylceramide from Cryptococcus neoformans inhibit cell budding and fungal growth. Infect. Immun. 68:7049-7060.

61. Gomez, F.J., Allendoerfer, R., and Deepe, G.S., Jr. 1995. Vaccination with recombinant heat shock protein 60 from Histoplasma capsulatum protects mice against pulmonary histoplasmosis. Infect. Immun. 63:2587-2595

62. Allendoerfer, R., Maresca, B., and Deepe, G.S., Jr. 1996. Cellular immune responses to recombinant heat shock protein 70 from Histoplasma capsulatum. Infect. Immun. 64:4123-4128.

63. Deepe, G.S., Jr., and Gibbons, R. 2001. Protective efficacy of H antigen from Histoplasma capsulatum in a murine model of pulmonary histoplasmosis. Infect. Immun. 69:3128-3134.

64. Dixon, D.M., et al. 1998. Development of vaccines and their use in the prevention of fungal infections. Med. Mycol. 36:57-67.

65. Stevens, D.A., et al. 2000. Combined treatment: antifungal drugs with antibodies, cytokines or drugs. Med. Mycol. 38:305-315.

66. Casadevall, A., and Pirofski, L. 2001. Adjunctive immune therapy for fungal infections. Clin. Infect. Dis. 33:1048-1056. 